CZASOPISMO INŻYNIERII LADDOWEJ, ŚRODOWISKA I ARCHITEKTURY JOURNAL OF CIVIL ENGINEERING, ENVIRONMENT AND ARCHITECTURE JCEEA, t. XXXII, z. 62 (3/II/15), lipiec-wrzesień 2015, s. 119-134

\author{
Grzegorz GREMZA ${ }^{1}$
}

Jan ZAMOROWSKI ${ }^{2}$

\title{
NIETYPOWA KONSTRUKCJA SPAWANEGO WEZZLA W JEDNOWARSTWOWEJ KRATOWNICY PRZESTRZENNEJ
}

\begin{abstract}
$\mathrm{W}$ artykule przedstawiono wielowątkową analizę niestandardowo ukształtowanych, rozgałęzionych węzłów konstrukcji kratowej o siatce trójkątnej. W konstrukcji tej pręty siatki utworzone $\mathrm{z}$ rur o przekroju kwadratowym spawano w węźle do tzw. rozety o kształcie foremnego graniastosłupa o podstawie sześciobocznej i wysokości w przybliżeniu równej bokowi podstawy, który był nieco większy od boku przekroju rury. Szczegółowej analizie poddano dwa warianty węzła. W pierwszym wariancie jeden z boków rury był zlicowany z jednym z denek rozety. $\mathrm{W}$ drugim występowało dodatkowe skręcenie pręta względem rozety, na skutek czego fragment rury wystawał ponad rozetę. Powodowało to konieczność wykonania niejednolitej konstrukcyjnie spoiny wzdłuż częściowo wystającej ścianki. Przeanalizowano sposób ukształtowania węzłów w odniesieniu do obowiązujących norm projektowania. Dokonano analitycznej oceny nośności połączenia spawanego. Prześledzono normowe uwarunkowania możliwości wykonania omawianych węzłów w klasie EXC3, zgodnie z klasyfikacją obowiązującą w normie wykonawczej dla konstrukcji stalowych EN-1090-2. W efekcie przeprowadzonych rozważań wnioskowano o technicznej możliwości wykonania takich złączy, przy spełnionych wymaganiach normowych w zakresie ich nośności i technologii wykonania. Oprócz analiz teoretycznych przedstawiono wyniki badań doświadczalnych elementów próbnych składających się z rozety i dwóch naprzemianlegle dołączonych do niej rur. Opisano stanowisko badawcze oraz elementy próbne wykorzystane w badaniach. Rozważania przedstawione w artykule uzupełniono o wybrane wyniki obliczeń numerycznych pierwszego z omówionych wariantów węzła, udostępnione przez współautora projektu konstrukcji.
\end{abstract}

Słowa kluczowe: wykonanie konstrukcji, połączenia spawane, badania, normy

\section{Wprowadzenie}

W przestrzennych konstrukcjach prętowych ze spawanymi węzłami bez

${ }^{1}$ Autor do korespondencji: Grzegorz Gremza, Politechnika Śląska, 44-100 Gliwice, ul. Akademicka 5, tel.662349538, ggre@interia.pl.

2 Jan Zamorowski, Akademia Techniczno-Humanistyczna, Bielsko-Biała, zamski@interia.pl. 
blach węzłowych, usytuowanymi na powierzchniach zakrzywionych, może zajść potrzeba wstępnego, beznaprężeniowego skręcenia krzyżulców celem dopasowania krawędzi ich przekrojów końcowych do konstrukcji węzła usytuowanego w płaszczyźnie stycznej do ich powierzchni. Przykładem takich konstrukcji mogą być siatkowe chłodnie kominowe - rys. 1a [1] czy kopuły - rys. 1b [2], o węzłach usytuowanych na powierzchniach osiowo-symetrycznych. Takie kształtowanie konstrukcji wymaga podjęcia dodatkowych czynności technologicznych i może prowadzić do wzrostu wytężenia jej elementów. Przykładowo, w wyniku wstępnego, beznaprężeniowego skręcenia krzyżulców w kopule ich wytężenie wzrosło o 6,6 \% [2]. W konstrukcji tego rodzaju występują także inne szczególne zagadnienia, np. stateczności węzła na przeskok.

a)

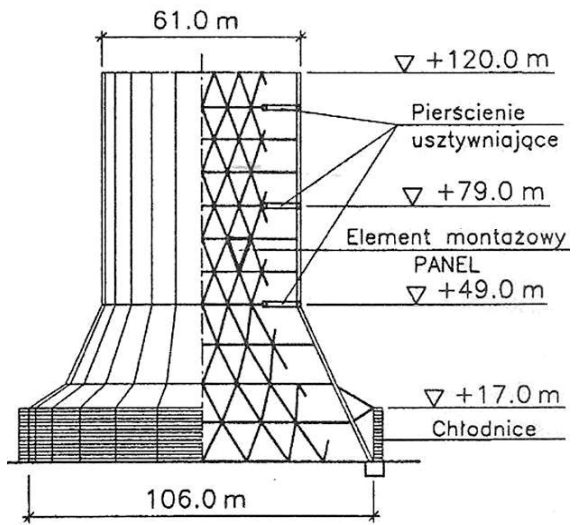

b)

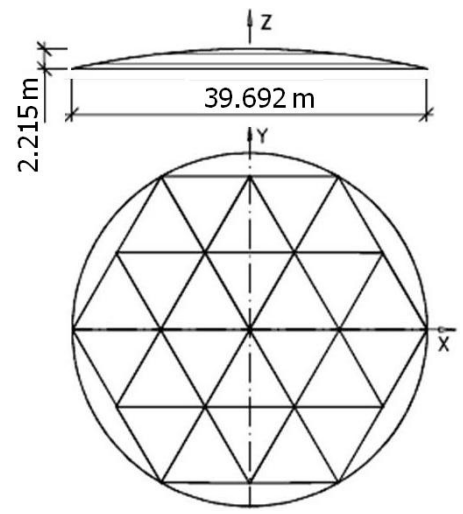

Rys. 1. Konstrukcje o powierzchniach zakrzywionych: a) chłodnia siatkowa [1], b) kopuła [2]

Fig. 1. Structures located on curved surfaces: a) lattice cooling tower, b) dome [2]

W nietypowym świetliku dachowym $\mathrm{z}$ rur kwadratowych, o strukturze siatki prętowej z trójkątnymi oczkami (o wymiarach w rzucie jak na rys. 2), węzły w postaci specjalnie skonstruowanych rozet usytuowane są na nieregularnie zakrzywionej powierzchni. W konstrukcji tej zrezygnowano ze wstępnego skręcenia prętów na ich długości, w wyniku czego ich krawędzie zostały wysunięte poza lico rozety - patrz opis w punkcie 2 artykułu.

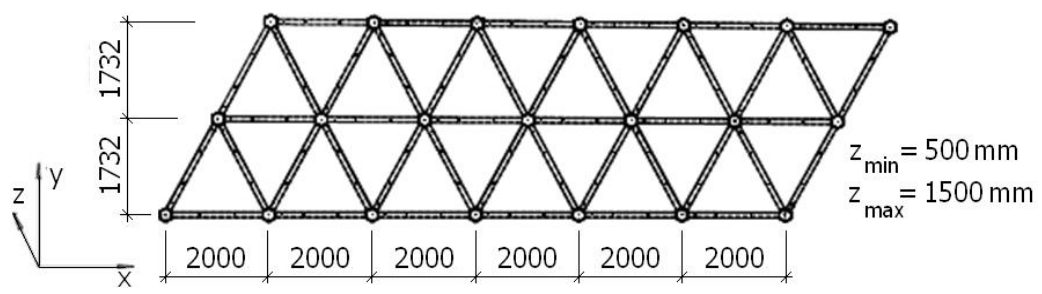

Rys. 2. Widok z góry na fragment konstrukcji siatki z rozetami [3]

Fig. 2. Top view on the part of grid roof structure with rosettes [3] 


\section{Konstrukcja węzla}

Rozety wykonano z blach zespawanych w formie sześciobocznego graniastosłupa jak na rys. 3 . Wymiary boków rozety były nieco większa niż szerokość boku rury. W zależności od węzła siatki, grubości boków rozety wynosiły 6 lub $8 \mathrm{~mm}[3]$.

a)

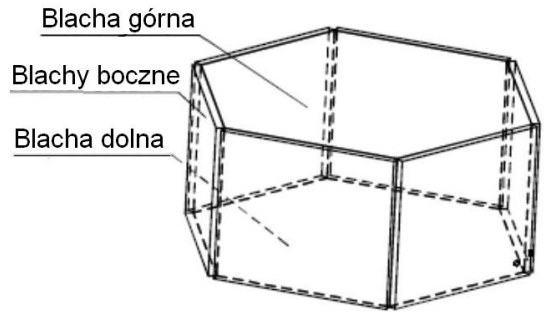

b)

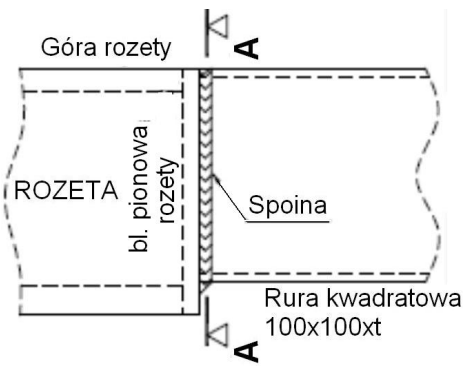

Rys. 3. Konstrukcja rozety [3]: a) widok ogólny rozety, b) widok z boku na połączenie

Fig. 3. Construction of the rosette [3]: general view of rosette, b) side view on connection

W wyniku zakrzywienia siatki, przywęzłowe przekroje prętów będą obrócone względem bocznych ścianek rozet. Sytuując rozety w węzłach siatki w płaszczyznach stycznych do jej powierzchni, można uzyskać równoległe ułożenie krawędzi przekroju rur $\mathrm{z}$ krawędziami boku rozety jedynie $\mathrm{w}$ wyniku wstępnego skręcenia prętów. Z uwagi na zaniechanie tego trudnego technologicznie zabiegu, zewnętrze krawędzie prętów nie są równoległe do odpowiadających im zewnętrznych krawędzi rozet. Licując krzyżulec na jednym końcu $\mathrm{z}$ rozetą (patrz rys. 4a) oraz licując jedno z naroży krzyżulca na drugim końcu, drugie $z$ naroży musi wystawać na zewnątrz rozety - patrz rys. 4b. Można również zlicować z rozetą naroże wystające, to wówczas drugie naroże będzie przesunięte do środka rozety - patrz rys. 4c. W węzłach przedmiotowej konstrukcji z uwagi na brak wstępnego skręcenia krzyżulców wystąpiły wszystkie te przypadki.

a)

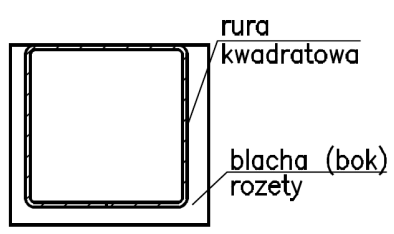

b)

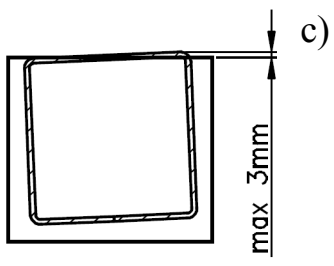

c)

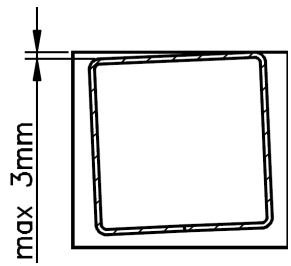

Rys. 4. Usytuowanie krzyżulca względem rozety [3] (przekroje A-A z rys. 3b)

Fig. 4. Location of a strut relative to rosette [3] (cross-sections A-A from Fig. 3b) 
a)

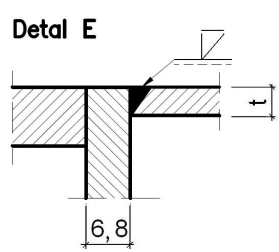

b)

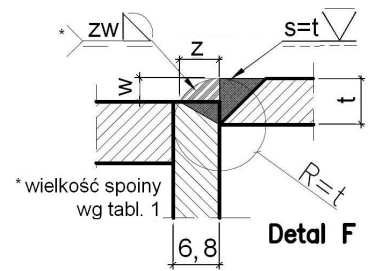

c)

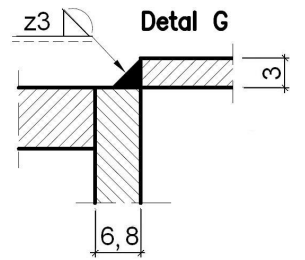

Rys. 5. Detale połączenia rury z rozetą [3]: a) spoina w narożu zlicowanym, b) spoina na długości zewnętrznej ścianki rury, c) spoina w narożu wystającym

Fig. 5. Details of welded joint pipe-rosette [3]: a) weld in an edge equalized to upper edge of the rosette, $b$ ) weld on the length of external wall of pipe, c) weld in jutting out edge

Krzyżulce $z$ rozetą na $3 / 4$ obwodu spawano spoiną pachwinową. Od górnej strony rozety na krawędziach zlicowanych jak na rys. 4a zaprojektowano spoinę czołową jak rys. 5a, natomiast na krawędziach częściowo wystających jak na rys. $4 \mathrm{~b}$ wykonano spoinę przechodzącą $\mathrm{z}$ czołowej w czołowo-pachwinową jak na rys. 5b. Wymiary tej spoiny przedstawiono w tablicy 1 . Konstrukcję wykonano ze stali S355JR i spawano metodą MAG (metoda 135). Minimalna grubość ścianki rury wynosiła $3 \mathrm{~mm}$, a maksymalna $10 \mathrm{~mm}$. Krawędź rury wystawała poza lico rozety nie więcej niż $3 \mathrm{~mm}$, niezależnie od jej grubości.

Tablica 1 . Wymiary spoiny z rys. $5 \mathrm{~b}$ wg [3]

Table 1. Dimension of weld from Fig. 5b according to [3]

\begin{tabular}{|c|c|c|c|c|c|c|c|c|c|c|c|}
\hline \multirow{2}{*}{$\begin{array}{l}\text { Wy- } \\
\text { miar }\end{array}$} & \multicolumn{11}{|c|}{ Detal } \\
\hline & $\mathrm{E}$ & \multicolumn{3}{|c|}{$\mathrm{F}$} & \multicolumn{3}{|c|}{$\mathrm{F}$} & \multirow{2}{*}{\multicolumn{4}{|c|}{$\frac{F}{25<w<3}$}} \\
\hline$w(\mathrm{~mm})$ & $w<0,5$ & & $5<w<1,5$ & & & $\overline{k w}$ & & & & & \\
\hline$t(\mathrm{~mm}):$ & 3 do 8 & 3 & $4,5,6$ & 8 & 3,4 & 5 & 6,8 & 3 & 4 & 5,6 & 8 \\
\hline$z(\mathrm{~mm})$ & - & 2 & 3 & 4 & 3 & 4 & 5 & 3 & 4 & 5 & 6 \\
\hline
\end{tabular}

\section{Uwarunkowania normowe}

\subsection{Uksztaltowanie geometrii węzla}

Ogólne zasady projektowania konstrukcji stalowych z materiału o grubości $\mathrm{t} \geq 3 \mathrm{~mm}$ zawarto $\mathrm{w}$ normie [7]. W normie [8] podano wymagania dla profilowanych na zimno kształtowników i blach poszycia. Przepisy dotyczące projektowania dowolnych węzłów ze stali od S235 do S460 o grubości elementów $\mathrm{t} \geq 4 \mathrm{~mm}$ oraz węzłów $\mathrm{z}$ kształtowników rurowych o $\mathrm{t} \geq 2,5 \mathrm{~mm}$ zamieszczono w normie [9]. Wymagania zawarte w normie [7] dotyczą obliczania konstrukcji i jej elementów, a w normach [8] i [9] oprócz przepisów dotyczących obliczania zawarto również wymagania dotyczące kształtowania węzłów. 
Zgodnie z pkt. 8.2(3) normy [8] styki i węzły skrajne należy tak kształtować, aby siły wewnętrzne były przekazywane do efektywnych części przekroju, a w pkt. 2.5(1) normy [9] stwierdza się, że węzły projektuje się na podstawie realistycznych założeń co do rozkładu sił wewnętrznych i momentów. W przedmiotowym węźle sposób przekazywania naprężeń z krzyżulców na węzeł jest zbliżony pod względem statycznym do występującego w węzłach $\mathrm{z}$ odstępem $w$ płaskich kratownicach $z$ rur RHS (rys. 6a). Naprężenia $z$ górnej ścianki rury są przekazywane bezpośrednio na górną blachę rozety, a ze ścianek dolnych w pobliżu dolnej blachy rozety przez jej blachy boczne (rys. 6b). Naprężenia ze ścianek rur prostopadłych do podstaw rozety przekazywane są na boczne blachy rozet, przy czym blachy te z uwagi na ich załamania w węźle pracują w lepszych warunkach niż płaskie ścianki w pasach płaskich kratownic. W zakresie statycznym rozwiązanie węzła jest prawidłowe.

a)

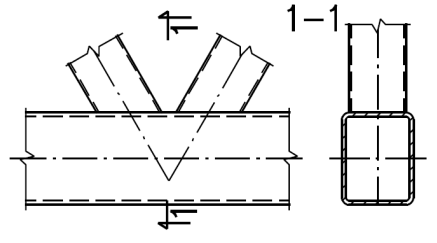

b)

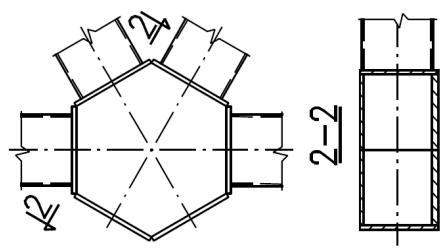

Rys. 6. Porównanie konstrukcji węzłów: a) węzła kratownicy płaskiej, b) rozpatrywanego węzła

Fig. 6. Comparison of joints: a) joint in plane truss, b) analysed joint

W pkt. 7.1.2(3) normy [9] zawarto wymaganie dotyczące kształtowania węzła, by kąty $\Theta_{i}$ między sąsiednimi prętami skratowania spełniały warunek $\Theta_{i} \geq 30^{\circ}$, a w pkt. 7.1.2(4), by końce prętów zbiegających się w węźle były przygotowane $\mathrm{w}$ taki sposób, aby ich kształt przekroju poprzecznego pozostał nie zmieniony. $\mathrm{W}$ przedmiotowym węźle kąty między krzyżulcami wynoszą $\sim 60^{\circ}$, a konstrukcja węzła $\mathrm{z}$ rozetą umożliwiła zachowanie niezmienionego kształtu końcowych, poprzecznych przekrojów krzyżulców i rygli. Oba wymagania są zatem spełnione.

W normie [6] w zakresie kształtowania węzłów zamieszczono zalecenie, w którym preferuje się węzły $z$ odstępem między prętami skratowania - patrz pkt. E.4a). Zalecenie to w przedmiotowym węźle również zostało zrealizowane.

\subsection{Projektowanie i wykonanie spoin}

Przepisy dotyczące wykonania stalowych konstrukcji spawanych zawarto w normach [5] i [6] oraz w normach $\mathrm{z}$ nimi związanych, a ponadto $\mathrm{w}$ zakresie kształtu spoin i ich wymiarów w normach [8] i [9]. Poniżej zamieszczono wyciąg z tych przepisów w zakresie dotyczącym przedmiotowego węzła, przy jego wykonaniu w klasie EXC3 oraz informację w jakiej części przepisy te dotyczą projektanta konstrukcji, a w jakiej powinny być wypełnione przez wykonawcę. 
W pkt. 7.1. normy [6] zawarto dwie ogólne informację dotyczące spawania:

- spawanie konstrukcji stalowych klasy EXC3 wykonuje się zgodnie z wymaganiami zawartymi w EN ISO 3834-2 [13],

- spawanie lukowe stali ferrytycznych wykonuje się zgodnie z wymaganiami i zaleceniami zawartymi w EN 1011-1 [10], EN 1011-2 [11]; w normach [10] i [11] zawarto ogólne wytyczne dotyczące właściwej produkcji i kontroli spawania wraz ze szczegółami określającymi zjawiska jakie mogą wystąpić z podaniem skutków i metod ich zapobiegania.

W normie [13] podano między innymi pełne wymagania jakości, dotyczące spawania w warunkach warsztatowych i/lub w warunkach budowy. Określono wymagania wobec podwykonawców, personelu wykonującego spawanie, nadzoru, personelu kontroli i badań, sprzętu do produkcji i badań, a także planowania produkcji, potrzeby przygotowania instrukcji technologicznej spawania i kwalifikowania technologii spawania, materiałów dodatkowych do spawania i badania, urządzeń produkcyjnych i badawczych, dokumentowania prac, materiałów dodatkowych i zapisów dotyczących jakości. Wszystkie te wymagania dotyczą wykonawcy konstrukcji. Zgodnie z pkt. $5.1 \mathrm{w}$ [13] wytwórca powinien przeglądać między innymi wymagania zawarte w umowie i ustalić czy wszystkie informacje konieczne do wykonania operacji wytwarzania są kompletne i dostępne przed rozpoczęciem pracy. Ponadto powinien zademonstrować swoją zdolność do spełnienia wszystkich wymagań oraz odpowiednio zaplanować wszystkie działania związane $\mathrm{z}$ zapewnieniem jakości. $\mathrm{Z}$ kolei, zgodnie z pkt. 7.2.1 w [6] wytwórca powinien sporządzić plan spawania jako składnik planu produkcyjnego wymaganego wg pkt. 10.1 normy [13].

W pkt. 7.4.1.1 normy [6] zawarto wymaganie aby spawanie było wykonywane $\mathrm{z}$ zastosowaniem kwalifikowanych technologii, wg instrukcji technologicznej spawania (WPS) zgodnej z odpowiednią częścią EN ISO 15609-1 [16]. Technologia ta zgodnie z pkt. 10.3 normy [13] powinna być kwalifikowana przed rozpoczęciem produkcji. Wg pkt. 7.4.1.2 w [6] kwalifikowanie technologii spawania w procesach 111, 114, 12, 13 i 14 zależy od klas wykonania, materiału podstawowego i stopnia zmechanizowania - patrz tabl. $12 \mathrm{w}$ [6]. W przypadku konstrukcji klasy EXC3 stosuje się dwie metody kwalifikacji technologii spawania: badanie technologii spawania wg EN ISO 15614-1 oraz przedprodukcyjne badania spawania wg EN ISO 15613. Jeśli procedurę kwalifikacyjną stosuje się do wytężonych poprzecznie spoin pachwinowych na stali gatunków wyższych niż S275, badania powinny być przeprowadzone na krzyżowej próbie rozciąganej zgodnie z EN ISO 9018. W pkt. 7.4.1.4 w [6] podano przepisy dotyczące ważności kwalifikacji technologii spawania, a w pkt. 7.4.2 w [6] dotyczące kwalifikacji spawania połączeń rozgałęzionych kształtowników rurowych o kącie odchylenia mniejszym niż $60^{\circ}$. Takie połączenia powinny być kwalifikowane za pomocą badań specjalnych.

W instrukcji WPS dotyczącej połączeń kształtowników rurowych w konstrukcji kratowej zgodnie z pkt. 7.4.1.1 normy [6] określa się strefy początku 
i końca oraz sposób przejścia spoiny pachwinowej w czołową na obwodzie złącza. Zastosowane w węźle przejście spoiny pachwinowej w czołową jak na rys. 5a od strony zlicowanego naroża wymagało odpowiedniego zukosowania ścianki rury w celu zachowania tej ciągłości, a przejście spoiny pachwinowej w czołowo-pachwinową jak na rys. 5b od strony wysuniętego naroża - zukosowania blachy rozety, co powinno być ujęte w instrukcji WPS.

W pkt. 8.5.1(2) normy [8] zawarto wymaganie aby grubość spoin była tak dobrana, by o nośności połączenia w połączeniach (zakładkowych) decydowała raczej nośność części łączonej lub blachy a nie nośność spoin. W pkt. 8.5.1(3) normy [8] uważa się, że wymaganie zawarte w pkt. 8.5.1(2) za spełnione, gdy grubość spoiny jest co najmniej równa grubości łączonej części lub blachy. W przedmiotowym złączu grubość spoiny pachwinowej z uwagi na jej nadlew została tak dobrana (patrz rys. 5c i tabl.1), że powyższe wymaganie zostało spełnione. Rachunkową ocenę tego stwierdzenia można dokonać za pomocą wzoru (8.4a) zawartego w [7], który dotyczy nośności spoiny pachwinowej, poprzecznej:

$$
F_{w, R d}=t L_{w e}\left(1-0,3 L_{w e} / b\right) f_{u} / \gamma_{M 2}
$$

gdzie: $t$ - grubość ścianki, $L_{w e}$ - długość spoiny.

Uwzględniając, że długość spoiny jest równa szerokości ścianki rury $\left(L_{w e}=b\right)$ uzyskuje się:

$$
F_{w, 1, R d}=0,7 t L_{w e} f_{u} / \gamma_{M 2}
$$

Wprowadzając do obliczeń wytrzymałość stali $f_{u}$ jak dla S235 i S355 oraz współczynniki częściowe $\gamma_{M 2}=1,25$ i $\gamma_{M 2}=1,10$ oraz $\gamma_{M 0}=1,00$, uzyskano nośność spoiny jak w tablicy 2.

Tablica 2. Nośności $1 \mathrm{~cm}$ spoiny i ścianki rury o grubości $3 \mathrm{~mm} \mathrm{wg}$ [8]

\begin{tabular}{|c|c|c|c|c|}
\hline \multirow{3}{*}{ Stal } & \multirow{2}{*}{\multicolumn{2}{|c|}{$\frac{\text { Nośność } 1 \text { cm spoiny } F_{w, l, R d}}{\mathrm{kN}}$}} & \multirow{2}{*}{\multicolumn{2}{|c|}{$\frac{\text { Nośność } 1 \text { cm ścianki rury } N_{l, R d}}{\mathrm{kN}}$}} \\
\hline & & & & \\
\hline & $\gamma_{M 2}=1,25^{* *}$ & $\gamma_{M 2}=1,10^{*}$ & $\gamma_{M 0}=1,00^{* *}$ & $\gamma_{M 0}=1,10$ \\
\hline 1 & 2 & 3 & 4 & 5 \\
\hline S235 & 6,05 & 6,87 & 7,05 & 6,41 \\
\hline S355 & 8,57 & 9,74 & 10,65 & 9,68 \\
\hline
\end{tabular}

Table 2. Load capacities of $1 \mathrm{~cm}$ weld and $1 \mathrm{~cm}$ wall of pipe with a thickness $3 \mathrm{~mm}$ acc. to [8]

Nośność spoiny (bez nadlewu) przy współczynnikach częściowych $\gamma_{M 2}=$ 1,10 (wartość współczynnika wg załącznika NA do [7]) oraz $\gamma_{M 0}=1,00$ wynosi 97,5\% nośności ścianki rury ze stali S235 oraz 91,5\% ze stali S355. Z kolei, 
spoina czołowo-pachwinowa w sposób ciągły przechodzi ze spoiny czołowej w pachwinową na całej szerokości rury. Jej nośność wyniesie odpowiednio 98,8\% i 95,8\% nośności ścianki rury. Jeśli przyjąć takie same wartości współczynników częściowych dla spoiny pachwinowej i ścianki to nośność spoiny jest nieco większa od nośności ścianki - porównaj kol. 3 i 5 tabl. 2.

Wg pkt. 7.5.11 w [6] połączenia rozgałęzione kształtowników rurowych w konstrukcjach kratowych, zawierające kombinowane złącza spawane (spoiny pachwinowe i jednostronne czołowe), mogą być spawane bez podkładek. Zgodnie z pkt. 7.5.9.2 w [6] szlifowanie na płasko jednostronnych spoin czołowych w złączach kształtowników rurowych wykonywanych bez podkładek jest niedopuszczalne, chyba że ustalono inaczej. Spoiny takie mogą być zeszlifowane na płasko do powierzchni kształtu materiału podstawowego, jeśli wykonano je w całości na podkładkach. Wymagania te dotyczą wykonania węzła.

Pozostałe wymagania zawarte $\mathrm{w}$ normie [6] w zakresie projektowania węzłów dotyczą zróżnicowania kształtu spoin w zależności od kąta nachylenia krzyżulca do pasa. Zgodnie z załącznikiem E do [6] spoinę czołową można stosować przy kącie $60^{\circ} \leq \Theta \leq 90^{\circ}$. W przypadku, gdy $\Theta<60^{\circ}$ to preferowana jest spoina pachwinowa, przy czym brzegi powinny być zukosowane jak do spawania czołowego - patrz pkt. 7.5.11 w [6]. Ponadto w pkt. 7.5.1.2 podano wymagania dotyczące kształtowników rurowych $\mathrm{z}$ rur okrągłych oraz przepis dotyczący przygotowania brzegów w połączeniach kształtowników rurowych do spawania jednostronnego, które powinno uwzględniać zalecenia EN ISO 96921 [15]. W zaleceniach tych podano między innymi sposoby przygotowania brzegów dla spoin czołowych (wymiary rowków do spawania) i spoin pachwinowych. W załączniku E do normy [6] podano przykłady tych zaleceń.

W kratownicach płaskich z rur RHS, ścianki rur równoległe do kratownicy oraz ścianki prostopadłe przy kącie $60^{\circ} \leq \Theta \leq 90^{\circ}$ można spawać spoinami czołowymi lub pachwinowymi, a ścianki prostopadłe przy kącie $30^{\circ} \leq \Theta<60^{\circ}$ tylko spoinami pachwinowymi - patrz pkt. E4 w [6], przy czym zgodnie z pkt. 7.4.1.1 normy [6] w instrukcji WPS należy określić strefy początku i końca oraz sposób przejścia spoiny pachwinowej w czołową na obwodzie złącza. Podobne rozwiązanie zastosowano w przedmiotowym złączu, przy czym ściankę równoległą do rozety $\mathrm{w}$ jej górnej części spawano spoiną czołowopachwinową, a pozostałe ścianki spoinami pachwinowymi przy kącie $\Theta=90^{\circ}$. Zgodnie z załącznikiem A do normy [6] (tabl.A1, pkt. 7.6) na rysunkach konstrukcyjnych zamieszczono dodatkowe informacje $w$ zakresie geometrii i kształtu spoiny czołowo-pachwinowej - patrz rys. 5 i tabl. 1.

Punkt 7.4.3 normy [6] dotyczy nadzoru spawalniczego, a w pkt. 12.4.2.2, 12.4.2.3 12.4.2.4 i 12.4.4 podano wymagania dotyczące zakresu kontroli spoin, w tym w konstrukcjach klasy EXC3 oraz badania produkcyjne spawania. Zaprojektowaną konstrukcję przedmiotowego złącza można wykonać w klasie EXC3. 


\section{Doświadczalne badania węzła}

\subsection{Cel i zakres badań, elementy próbne}

Celem badań było określenie nośności niestandardowego elementu konstrukcyjnego (rys. 7) składającego się z rozety i dwóch rur RHS ze stali S355, odchylonych względem siebie o kąt $180^{\circ}$ i przyspawanych do rozety w sposób analogiczny jak krzyżulce w konstrukcji świetlika dachowego. W elementach próbnych zastosowano rozety o wysokości $\sim 110 \mathrm{~mm}$ i szerokości boku $\sim 120 \mathrm{~mm}$ oraz rury kwadratowe o boku $100 \mathrm{~mm}$ i grubości $3 \mathrm{~mm}$. Ścianki boczne oraz jedno z denek rozety wykonano z blachy o grubości $6 \mathrm{~mm}$, a drugie z blachy o grubości $10 \mathrm{~mm}$. Rury zamocowano do rozety niewspółśrodkowo względem jej ścianek, przesuwając je w kierunku strony o cieńszym denku. Końcówki rur wzmocniono nakładkami z blachy grubości $20 \mathrm{~mm}$ w celu zwiększenia ich nośności na docisk trzpienia mocującego próbki w stanowisku badawczym.
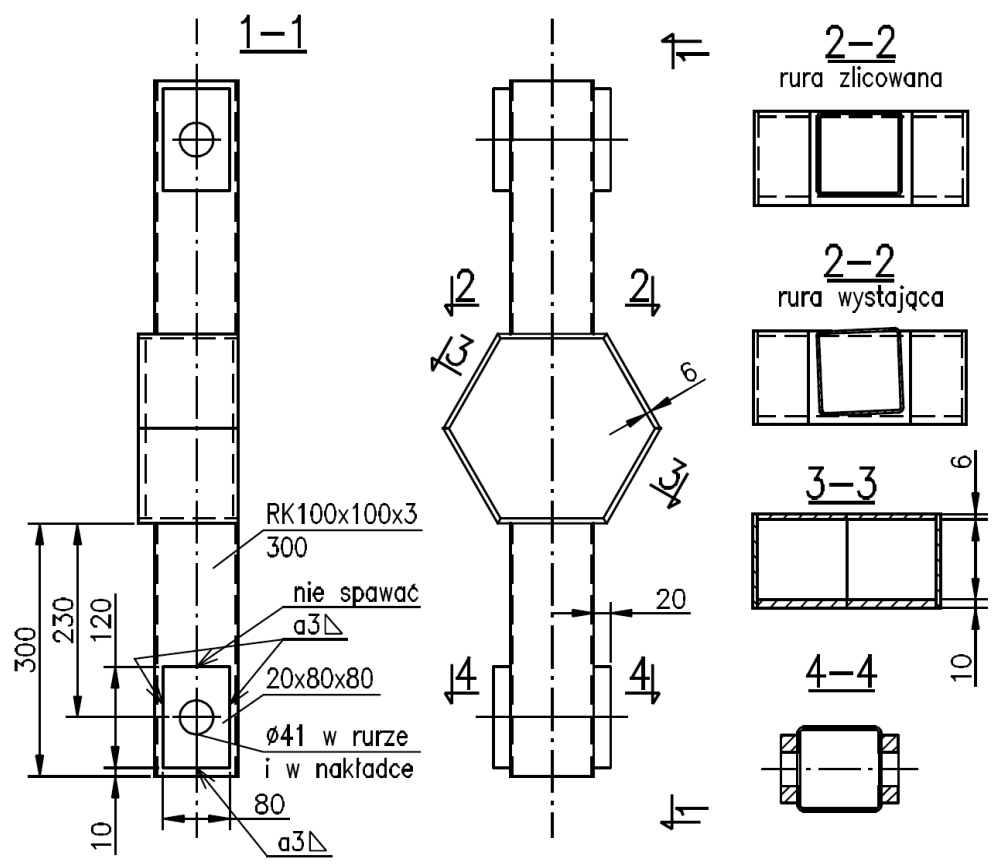

Rys. 7. Konstrukcja elementu próbnego

Fig. 7. Construction of specimen

Badaniom poddano dwa zestawy próbek, po trzy próbki w każdym zestawie. W pierwszym zestawie rury były usytuowane względem rozety jak na rys. $4 \mathrm{~b}$ i przyspawane do rozety trzema spoinami pachwinowymi i jedną spoiną czołowopachwinową o charakterystykach geometrycznych jak na rys. 5b i w tabl. 1. 
W drugim (kontrolnym) zestawie rury ustawiono względem rozety jak na rys. 4a i przyspawano do rozety trzema spoinami pachwinowymi i jedną czołową. Fotografię próbek przed badaniem przedstawiono na rys. 8 .

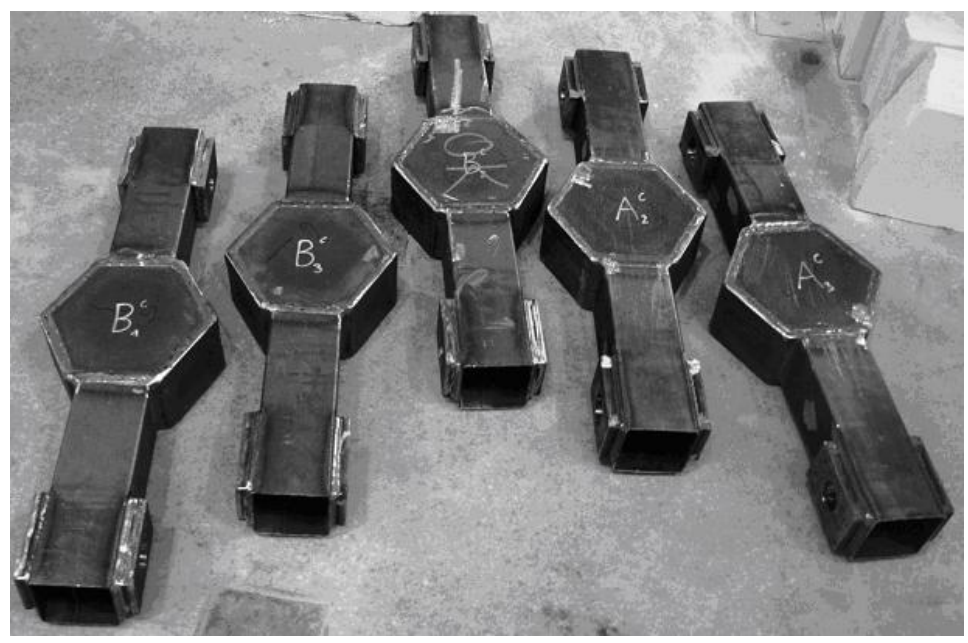

Rys. 8. Elementy próbne

Fig. 8. The test specimens

W celu sprawdzenia granicy plastyczności i wytrzymałości materiału zastosowanego na rury, przebadano trzy próbki materiału pobrane ze środkowej części ścianki rury pozostałej po produkcji elementów próbnych.

\subsection{Opis stanowiska badawczego}

Konstrukcja stanowiska badawczego o schemacie przedstawionym na rys. 9 umożliwiała osiowe przekazywanie siły rozciągającej na badane elementy. Stanowisko to składało się z ramy stalowej zakotwionej w płycie dużych sił, siłownika oraz dodatkowych elementów od A do E. Elementy próbne z jednej strony kotwiono w tzw. płycie dużych sił za pomocą śruby M64 i elementów łączących D i E, a z drugiej strony za pomocą elementu E do jarzma składającego się z dwóch belek - dolnej (element B) i górnej (element A), połączonych cięgnami (elementy $\mathrm{C}$ ). Siłownik umieszczono na ryglu ramy pod górną belką jarzma. Rozciąganie elementu próbnego następowało w wyniku przemieszczania do góry górnej belki jarzma. Po zniszczeniu elementu próbnego usuwano sworznie E i wyjmowano części zerwanego elementu. 


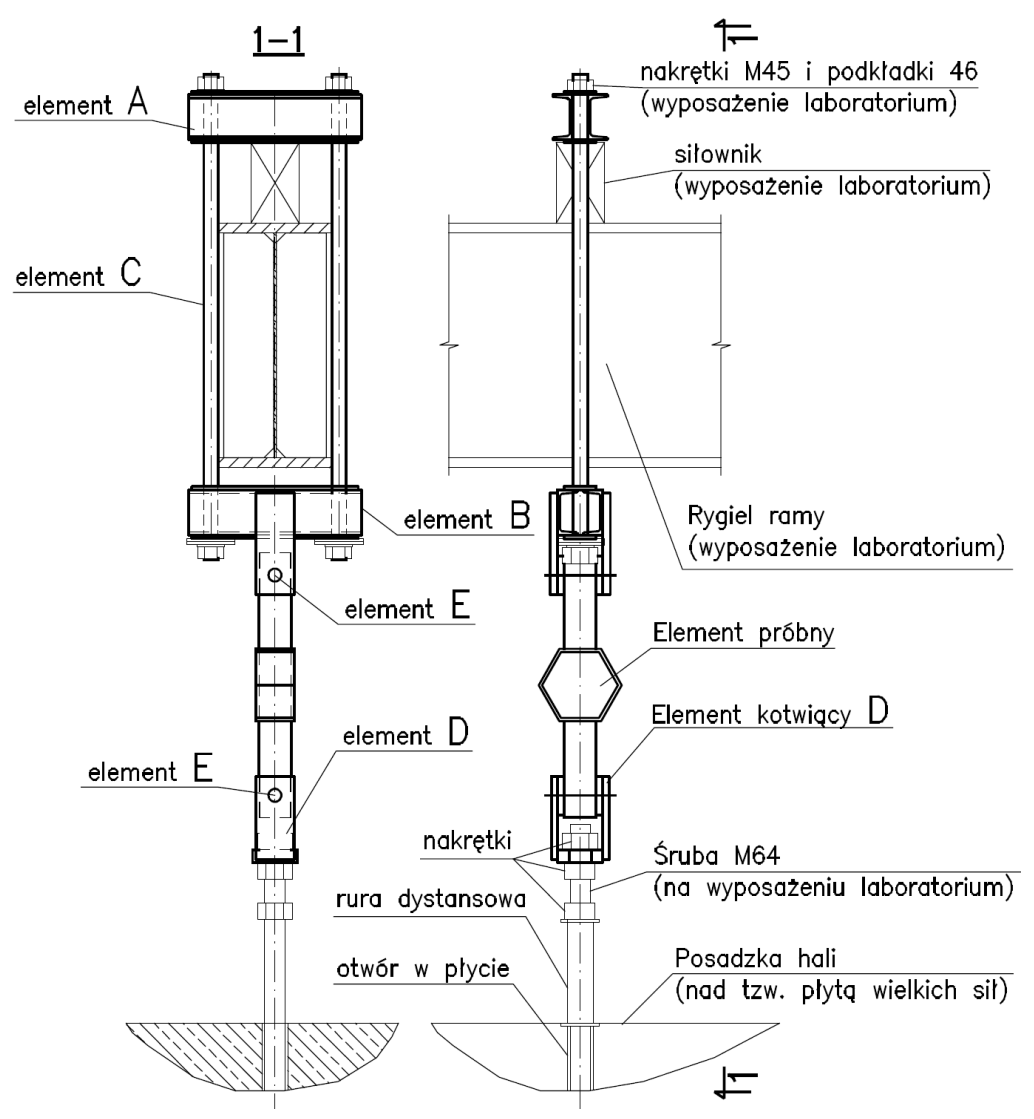

Rys. 9. Schemat stanowiska badawczego

Fig. 9. Test arrangement

\subsection{Przebieg badań, obciążanie elementów}

Wartość siły obciążającej określano na podstawie pomiaru ciśnienia i średnicy tłoka zastosowanego siłownika, równej $130 \mathrm{~mm} ; 1$ bar na manometrze oznaczał obciążenie $4 / 3 \mathrm{kN}=1,33 \mathrm{kN}$. W trakcie badania, na bieżąco korzystano z wykresu i tablicy z odpowiednim przeliczeniem ciśnienia na siłę.

Obciążenia przykładano w sposób możliwie ciągły, z prędkością uzależnioną od stosunku powierzchni tłoków dostępnej pompy i zastosowanego siłownika oraz długości dźwigni pompy i fizycznych możliwości obsługującego urządzenie. Uzyskana prędkość obciążania pozwalała na spełnienie wymagań dotyczących prędkości narastania odkształceń przy ustalaniu $R_{m}$ w typowej próbie statycznego rozciągania na małej próbce, to jest prędkości odkształcenia $\mathrm{w}$ całym zakresie obciążania nie większej niż $0,008 \mathrm{~s}^{-1}$. Osiągnięcie prędkości obciążania między $6 \mathrm{MPa} / \mathrm{s}$ a $60 \mathrm{MPa} / \mathrm{s}$ wymaganej przy określaniu granicy plastyczności na małych próbkach według [19] nie było możliwe przy tak dużym 
elemencie, z uwagi na charakterystyki zastosowanego układu hydraulicznego. Zwykle w badaniach elementów konstrukcyjnych pod obciążeniem statycznym tak wysokie prędkości obciążania nie są stosowane. Powolne przykładanie obciążenia odpowiada warunkom pracy większości elementów konstrukcyjnych budynków, w tym świetlików obciążanych głównie ciężarem własnym i śniegiem.

W ciągu pierwszej minuty badania obciążenie osiągało wartość około $130 \mathrm{kN}$, przy naprężeniu w przekroju rury $115 \mathrm{MPa}$, co oznacza uśrednioną prędkość obciążania $\sim 1,9 \mathrm{MPa} / \mathrm{s}$. Po czterech minutach osiągano wartość około $400 \mathrm{kN}$, przy naprężeniu w przekroju rury $\sim 350 \mathrm{MPa}$ i prędkości obciążania między pierwszą i czwartą minutą $\sim 1,3 \mathrm{MPa} / \mathrm{s}$. Do chwili osiągnięcia wartości zbliżonej do $R_{m}$, średnia prędkość przyrostu naprężenia wynosiła około $0,6 \mathrm{MPa} / \mathrm{s}$. Całkowity czas przebiegu obciążania elementów próbnych do chwili ich zniszczenia wynosił około 15 minut.

\subsection{Wyniki badań}

Wartości sił obciążających elementy w chwili ich zniszczenia (nośności doświadczalne) zestawiono w pierwszym wierszu tablicy 3. Są to wskazania siłownika pomniejszone o ciężar usprzętowienia, który wynosił $1,3 \mathrm{kN}$. $\mathrm{W}$ wierszu drugim zamieszczono naprężenia uśrednione, obliczone jako iloraz uzyskanej nośności do początkowego pola przekroju rury. Przekraczały one nieco wartości $f_{u}=R_{m}=510 \mathrm{MPa}$, zamieszczone w normie [7].

Tablica 3. Wyniki badań

Table 3. Test results

\begin{tabular}{|c|c|c|c|c|c|c|c|}
\hline \multirow{2}{*}{$\begin{array}{l}\text { Opis charak- } \\
\text { terystyk }\end{array}$} & \multirow{2}{*}{$\begin{array}{c}\text { Jed- } \\
\text { nost } \\
\text { ka }\end{array}$} & \multicolumn{3}{|c|}{$\begin{array}{c}\text { Próbki ze spoinami } \\
\text { czołowo-pachwinowymi }\end{array}$} & \multicolumn{3}{|c|}{$\begin{array}{c}\text { Próbki ze spoinami } \\
\text { czołowymi }\end{array}$} \\
\hline & & 1 & 2 & 3 & 1 & $2^{3)}$ & 3 \\
\hline 1 & 2 & 3 & 4 & 5 & 6 & 7 & 8 \\
\hline Nośność & $\mathrm{kN}$ & 596 & 588 & 588 & 602 & 582 & 596 \\
\hline $\begin{array}{l}\text { Maksymalne } \\
\text { naprężenie }\end{array}$ & $\mathrm{MPa}$ & 523 & 516 & 516 & 528 & 511 & 523 \\
\hline $\begin{array}{l}\text { Przypadek } \\
\text { zniszczenia }\end{array}$ & - & 2 & 1 & 1 & 2 & 2 & 2 \\
\hline Strona próbki ${ }^{2)}$ & - & góra & dół & góra & dół & góra & góra \\
\hline
\end{tabular}


We wszystkich elementach zerwaniu uległa rura w przekroju usytuowanym bezpośrednio powyżej styku rury z rozetą (przypadek 1 - rys. 10a) lub w pobliżu uchwytu (przypadek 2 - rys. 10b). W miejscu rozerwania ścianki zawsze występowało wyraźne przewężenie, co świadczy o braku kruchego pęknięcia materiału rodzimego. Niezależnie od przypadku zniszczenia, nośności elementów próbnych były bardzo do siebie zbliżone i różniły się od siebie maksymalnie o $3,4 \%$.

a)

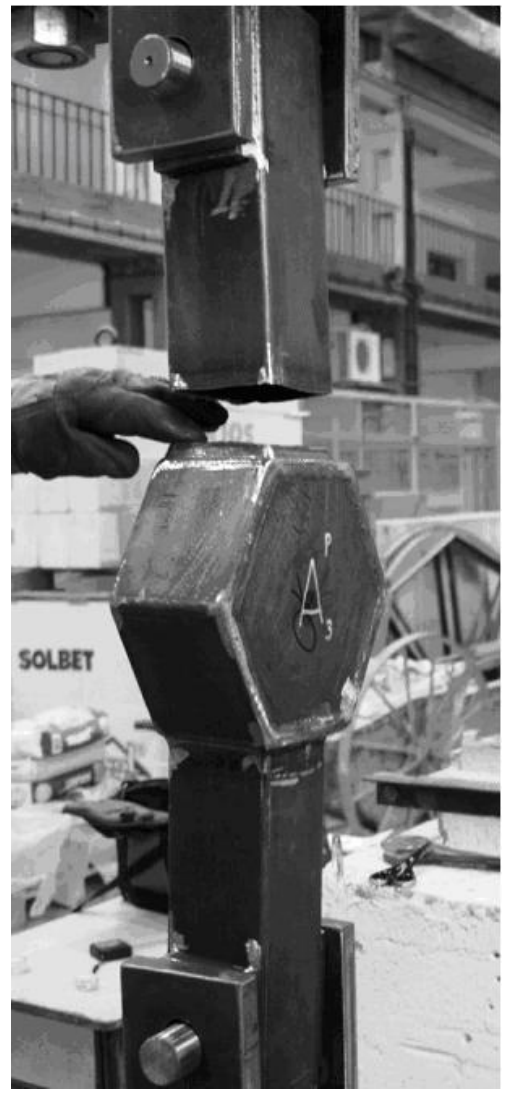

b)

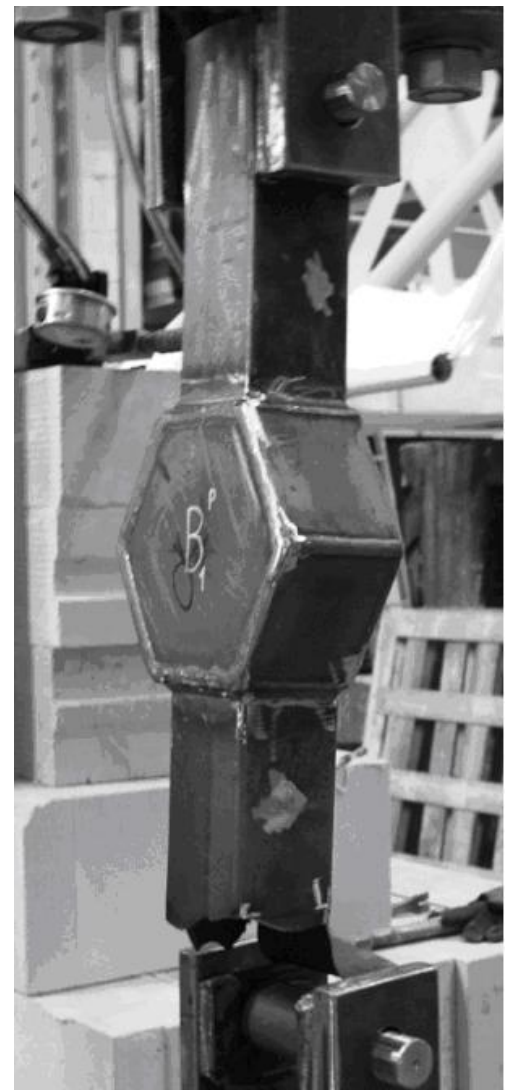

Rys. 10. Próbki po zniszczeniu: a) w przekroju nad spoiną, b) w przekroju nad uchwytem

Fig. 10. Samples after test: a) cracked in cross-section upon weld, b) cracked upon grip

W badanych elementach przed pojawieniem się przewężenia materiału, rejestrowano wydłużenie bazy pomiarowej o długości $40 \mathrm{~cm}$, rzędu $5 \div 6 \mathrm{~mm}$, co jest równoznaczne z odkształceniem rzędu $13 \div 15$ promili. Badane elementy były zatem uplastycznione, a nośność spoin była większa od nośności rur. Średnia wytrzymałość na rozerwanie próbek kontrolnych wynosiła $512 \mathrm{MPa}$. 


\section{Analizy numeryczne węzła}

W analizach numerycznych [4] przeanalizowano dwa elementy ze stali S355. Pierwszy z nich składał się z rozety oraz dwóch dołączonych do niej rur 100x100x3 mm (rys. 11a). W drugim elemencie (rys. 11b) do rozety dołączono komplet sześciu rur, podobnie jak ma to miejsce w większości węzłów zrealizowanej konstrukcji. W analizowanych numerycznie elementach jedną ze ścianek rury zlicowano z krawędzią rozety, wprowadzając jednostronne spoiny czołowe $\mathrm{z}$ nadlewem. W przeanalizowanych węzłach nie uwzględniono przypadku, gdy ścianka rury wystaje częściowo nad rozetę. Prowadzono analizę materiałowo nieliniową, przyjmując model sprężysto-plastyczny.

a)

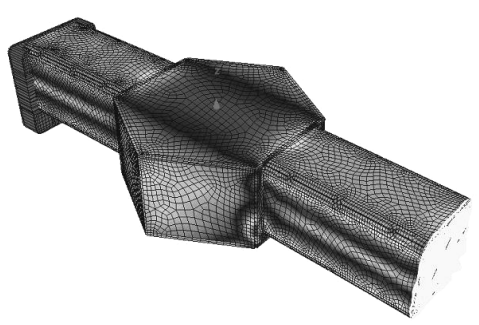

b)

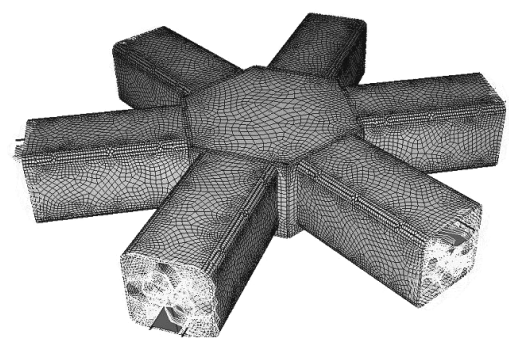

Rys. 11. Modele numeryczne MES elementów [4]: a) wariant 1, b) wariant 2

Fig. 11. Numerical FEM models of the joints [4]: a) variant 1, b) variant 2

W wyniku analizy numerycznej pierwszego z elementów uzyskano wartość obciążenia granicznego przy osiowym rozciąganiu równą $78 \%$ nośności plastycznej przekroju rury na rozciąganie $N_{p l}$, a w przypadku czystego zginania równą $88 \%$ nośności plastycznej przekroju rury na zginanie $M_{p l}$. W wyniku analizy drugiego z elementów, w którym końce wszystkich sześciu rur obciążono momentem zginającym, uzyskano w połączeniu taki sam jak w pierwszym elemencie stosunek wartości granicznej obciążenia do nośności plastycznej przekroju rury przy zginaniu.

Uzyskany doświadczalnie stopień wykorzystania nośności przekroju rury określany jako iloczyn jej pola przekroju i granicy plastyczności stali był większy od otrzymanego w analizach numerycznych. Różnice związane były prawdopodobnie z szybszą utratą zbieżności rozwiązania w programie, wynikającą $\mathrm{z}$ pominięcia $\mathrm{w}$ modelu materiałowym umocnienia stali po przekroczeniu granicy plastyczności.

\section{Wnioski}

Na podstawie przeprowadzonych badań eksperymentalnych stwierdzono, że nośność analizowanych połączeń była nie mniejsza niż obciążenie powodujące uplastycznienie przekrojów łączonych do rozety rur. We wszystkich ele- 
mentach odnotowano odkształcenia trwałe, a występujące wyraźne przewężenie przy spoinie świadczy, że nie zachodziło pękniecie kruche. Jednocześnie na podstawie analizy uwarunkowań normowych stwierdzono, że możliwe jest wykonanie rozpatrywanego węzła w klasie EXC3.

\section{Literatura}

[1] Zamorowski J.: Obliczanie chłodni kominowej według teorii II rzędu. IX International Conference on Metal Structures, Kraków 1995, t. s. 85-94.

[2] Zamorowski J.: Ocena wpływu wybranych imperfekcji geometrycznych na wytężenie prętów w mało wyniosłej kratownicy przestrzennej, VIII MKN-T KM, Gdańsk 1989, t.2, s. 209-216.

[3] Konsorcjum Zeman-Dachy-Fasady Sp. z o.o., Opal Spółka z o.o. Spółka komandytowa: Wybrane rysunki projektu wykonawczego podziemnej stacji i dworca multimodalnego Łódź Fabryczna: ZEMI 1-PW4-DWK-BB-CME-16027-0.2. Świętochłowice $06.2014 \mathrm{r}$.

[4] Rabijasz M.: Wyciąg z analizy numerycznej połączeń rur z rozetą dla projektu wykonawczego podziemnej stacji i dworca multimodalnego Łódź Fabryczna (niepublikowane).

[5] PN-EN 1090-1+A1:2012: Wykonanie konstrukcji stalowych i aluminiowych. Część 1: Zasady oceny zgodności elementów konstrukcyjnych.

[6] PN-EN 1090-2+A12012: Wykonanie konstrukcji stalowych i aluminiowych. Część 2: Wymagania techniczne dotyczące konstrukcji stalowych.

[7] PN-EN 1993-1-1: 2006 +AC: $2009+$ Ap1: 2010+NA:2010+A1:2014.07: Eurokod 3: Projektowanie konstrukcji stalowych Część 1-1: Reguły ogólne i reguły dla budynków.

[8] PN-EN 1993-1-3: 2008+NA:2010: Eurokod 3: Projektowanie konstrukcji stalowych. Część 1-3: Reguły ogólne. Reguły uzupełniające dla konstrukcji z kształtowników i blach profilowanych na zimno.

[9] PN-EN 1993-1-8:2006+NA:2010+NA:2011+ Ap1: 2010 + Ap2: 2011: Eurokod 3: Projektowanie konstrukcji stalowych Część 1-8: Projektowanie węzłów.

[10] PN-EN 1011-1:2009 (tylko wersja angielska): Spawanie. Zalecenia dotyczące spawania metali. Część 1: Ogólne wytyczne dotyczące spawania łukowego.

[11] PN-EN 1011-2:2004/A1:2005: Spawanie. Wytyczne dotyczące spawania metali. Część 2: Spawanie łukowe stali ferrytycznych.

[12] PN-EN ISO 3834-1:2007 Wymagania jakości dotyczące spawania materiałów metalowych - Część 1: Kryteria wyboru odpowiedniego poziomu wymagań jakości.

[13] PN-EN ISO 3834-2:2007 Wymagania jakości dotyczące spawania materiałów metalowych - Część 2: Pełne wymagania jakości.

[14] PN-EN ISO 9018:2008: Badania niszczące spoin w metalach -- Badanie na rozciąganie złączy krzyżowych i zakładkowych.

[15] PN-EN ISO 9692-1:2014-02 (wersja angielska, jest wcześniejsza wersja polska): Spawanie i procesy pokrewne. Rodzaje przygotowania złączy. Część 1: Ręczne 
spawanie łukowe, spawanie łukowe elektrodą metalową w osłonie gazów, spawanie gazowe, spawanie metodą TIG i spawanie wiązką stali.

[16] PN-EN ISO 15609-1:2007: Specyfikacja i kwalifikowanie technologii spawania metali -- Instrukcja technologiczna spawania. Część 1: Spawanie łukowe.

[17] PN-EN ISO 15613:2006: Specyfikacja i kwalifikowanie technologii spawania metali. Kwalifikowanie na podstawie przedprodukcyjnego badania spawa$\mathrm{nia} /$ zgrzewania.

[18] PN-EN ISO 15614-1:2008: Specyfikacja i kwalifikowanie technologii spawania metali - Badanie technologii spawania - Część 1: Spawanie łukowe i gazowe stali oraz spawanie łukowe niklu i stopów niklu.

[19] PN-EN ISO 6892-1: 2010: Metale-Próba rozciągania-Część 1: Metoda badania w temperaturze otoczenia.

\section{UNTYPICAL CONSTRUCTION OF WELDED JOINT IN SPACE SINGLE-LAYER TRUSS}

\section{S u m m a r y}

A multi-aspect analysis of untypically shaped multi-branch connections in nodes of singlelayer triangular spatial grid has been presented in that article. The bars made of the square pipes which formed a grid has been welded to so called rosette, placed in the node, with a shape of regular hexagonal prism with a height nearly equal to the length of the base edge, that was slightly larger than the dimension of a side of the pipe. Two variants of a joint was analysed in detail. In the first variant one side of the pipe was equalized to the upper edge of the rosette. In the second one an additional twisting of the bar relative to the rosette occurred. As a result, a fragment of the pipe protruded above the rosette what caused the necessity of performing a nonuniform weld along the side of the partially protruding pipe. The way of shaping the joints in accordance to the design standards being in force was analysed. The analytical assessment of a load capacity of the welded joint was made, as well. The standard feasibility requirements of the performing possibility the discussed joints in EXC3 class, according to a classification given by a harmonized standard EN-1090-2 for executing of steel structures, have been tracked. As a result of considerations carried out in the article the conclusions about the technical possibilities of executing such joints, with fulfilled requirements in terms of their load capacity and technology of their execution, were presented. Besides the theoretical analyses the article presents the results of the experimental researches that have been carried out on specimens composed of two pipes located on the opposite sides of the rosette. The test arrangement and the specimens that have been used in the experiment were described in that paper. Considerations that have been presented in the article were supplemented with the selected results of the numerical analysis of the first variant of joint, that were provided by co-author of the discussed structure design [4].

Keywords: execution of steel structures, welded joints, experimental tests, standard rules

Przestano do redakcji:30.05.2015

Przyjęto do druku:1.12.2015

DOI: $10.7862 / \mathrm{rb} .2015 .144$ 